RASĀYAN J. Chem.

Vol. 13 | No. 1 |215 - 221| January - March | 2020 ISSN: 0974-1496 | e-ISSN: 0976-0083 | CODEN: RJCABP

RJC http://www.rasayanjournal.com http://www.rasayanjournal.co.in

\title{
SYNTHESIS, CHARACTERIZATION AND ANTIMICROBIAL ACTIVITY OF Mn(II),Fe(II), Ni(II),Co(II) AND Zn(II) COMPLEXES OF SCHIFF BASE DERIVED FROM 2,2- DIMETHYLPROPANE 1, 3-DIAMINE AND 5-CHLORO ISATIN
}

\author{
N. P. Singh ${ }^{1, *}$, K. Kumar², A. Kumar ${ }^{2}$ and U. Agarwal ${ }^{2}$ \\ ${ }^{1}$ Department of Chemistry, Deen Dayal Upadhyay Gorakhpur University, \\ Gorakhpur-273009 (UP) India \\ ${ }^{2}$ Department of Chemistry, Meerut College, Meerut-250002 (UP) India \\ *E-mail: npsmcm.in@gmail.com
}

\begin{abstract}
A new Schiff base Ligand $(\mathrm{L})($ where $\mathrm{L}=3 \mathrm{Z}, 3 \mathrm{Z}$ Z)-3,3'-((2,2-dimethylpropane-1,3-diyl)bis(azanylyidene))bis(5chloroindolin-2-one) has been synthesized by condensation of 5-Chloroisatin and 2, 2-dimethyl propane-1, 3diamine respectively in the molar ratio of 2:1.The synthesized ligand(L) was used to synthesis metal complexes of transition metals ( $\mathrm{Mn}(\mathrm{II}), \mathrm{Fe}(\mathrm{II}), \mathrm{Co}(\mathrm{II}), \mathrm{Ni}(\mathrm{II})$, and $\mathrm{Zn}(\mathrm{II})$ ). The ligand and its metal complexes have been characterized by elemental analysis, FT-IR, UV-Visible, ESI-Mass spectrometry and ${ }^{1} \mathrm{H}-\mathrm{NMR}$ and ${ }^{13} \mathrm{C}-\mathrm{NMR}$ spectra. On the basis of Spectral data it is revealed that the ligand is N, N, O, O tetradentate and coordinated to the metal ion to both azomethine $\mathrm{N}$ atoms and $\mathrm{O}$ atoms of lactum group. All the metal complexes show octahedral geometry except $\mathrm{Ni}(\mathrm{II})$ and $\mathrm{Zn}(\mathrm{II})$ they possess square planar geometry. The ligand and its metal complexes were tested for antibacterial activities. Metal Complexes showed better antibacterial activities as compare to Ligand.

Keywords: Schiff Base, Metal(II) Complexes, 2,2-Dimethylpropane-1,3-diamine, 5-Chloroisatin, Octahedral Geometry, Antimicrobial activity.
\end{abstract}

(C) RASĀYAN. All rights reserved

\section{INTRODUCTION}

Schiff base ligands usually contain $\mathrm{O}$ and $\mathrm{N}$ donor atoms have played important role in coordination chemistry and recently considerable attention has been paid to the chemistry of the metal complexes of Schiff base containing nitrogen and other donors. This may be attributed to their stability, biological activity and potential applications in many fields such as oxidation, catalysis, electrochemistry. Tetradentate Schiff base is one of the most extensively studied ligands in the coordination chemistry. They can coordinate with large number of transition metals. One type of Schiff base ligand is N, N, O, Otetradentate donor set which possesses many advantages such as facile approach, relative tolerance, readily adjusted ancillary ligands and tuneable steric and electronic coordination environments on the metal centre. ${ }^{1-3}$ Isatin (1H-Indoline-2, 3-dione) is an endogenous compound isolated in 1841 by Erdman and Laurent as a product from oxidation of indigo by nitric acid \& chromic acid and reported to possess a wide range of activities involving the central nervous system. ${ }^{4-7}$ Isatin and its Schiff base derivatives and Mannich bases have been reported to possess a variety of biological and pharmacological activities as antimicrobial, ${ }^{8}$ antidepressant , cytotoxicity, analgesic, anticonvulsant, insecticides, DNA Binding, ${ }^{9}$ anticancer, tuberculostatic, and anti-inflammatory, antibacterial, antifungal, antiviral, anti-HIV, ${ }^{10-19}$ and antiheliminthic activities. ${ }^{20,21}$ These complexes not only play an important role in the development of coordination chemistry related to catalysis and enzymatic reactions, magnetism and molecular architectures, ${ }^{22-24}$ but also exhibit interesting biological activities. ${ }^{25}$ Most of the compounds show versatile biological properties such as antioxidant, ${ }^{26}$ especially antibacterial activities. ${ }^{27-29}$

Rasayan J. Chem., 13(1), 215-221(2020)

http://dx.doi.org/10.31788/RJC.2020.1315571 
RASĀYAN J. Chem.

Vol. 13 | No. 1 | 215 - 221| January - March | 2020

Although much attention has been paid directed to study of Schiff base and Mannich bases derived from Isatin, no investigations have been appeared in the literature to describe the Schiff bases derived from 2, 2-Dimethylpropane 1,3-diamine and 5-chloroisatin. Therefore as a part of our ongoing study on Schiff base derived from 2,2-Dimethylpropane1,3-diamine,we reported herein the synthesis, characterization and antibacterial activity of novel Schiff base formed by condensation of 5-Chloroisatin and 2, 2Dimethylpropane1,3-diamine(Scheme-1) and its metal complexes of $\mathrm{Mn}(\mathrm{II}), \mathrm{Fe}(\mathrm{II}), \mathrm{Co}(\mathrm{II}), \mathrm{Ni}(\mathrm{II})$ and $\mathrm{Zn}(\mathrm{II})$ (Scheme-2).

\section{EXPERIMENITAL}

The Chemicals, 5-Chloroisatin and 2, 2-Dimethylpropane1, 3-diamine of analytical grades were purchased from sigma Aldrich. Solvents such as Ethanol, glacial acetic acid, Methanol, Diethyl ether and hydrated metal acetate/chloride salts were purchased from Qualigen. Chemicals and solvents were used as received without further purification. Melting points were determined by using open capillary method and were uncorrected. The infrared (IR) spectra were recorded on perkin Elmer system 2000 FTIR spectrometer by KBr Disc methods $\left(4000-400 \mathrm{~cm}^{-1}\right)$. The ES-Mass Spectra were recorded on Agilent QTOF LC-MS mass Spectrometer. ${ }^{1} \mathrm{H}$ NMR and ${ }^{13} \mathrm{C}$ NMR spectra were recorded on Bruker 400 or 300 $\mathrm{MHz}$ spectrometer at $25^{\circ} \mathrm{C}$ using tetramethylsilane as an internal standard and DMSO- $\mathrm{d}_{6}$ as solvent.

\section{Synthesis of Schiff Base(L)}

To ethanolic solution of 2, 2-Dimethyl Propane 1, 3-diamine $(10 \mathrm{mmol}, 1.02 \mathrm{~g})$ in 20ml, ethanolic solution of 5- Chloroisatin ( $20 \mathrm{mmol}, 3.620 \mathrm{gm})$ was added. The two hot solutions were mixed in $250 \mathrm{ml}$ round bottom flask in presence of few drops of glacial acetic acid as catalyst. The resulting mixture was refluxed for $8 \mathrm{~h}$ at $80-90^{\circ} \mathrm{C}$. The reaction was monitored with TLC and then after cooling at room temperature, poured in to ice-cold water. The precipitate was filtered off, washed with water, cold ethanol, dry diethyl ether respectively and air dried at room temperature with yield $66 \%$ (Scheme-1).

\section{Synthesis of Complexes (Scheme-2)}

(a) Synthesis of $\left[\mathrm{MnL}\left(\mathrm{H}_{2} \mathrm{O}\right)_{2}\right] 2 \mathrm{AcO}$

To ethanolic solution of $\mathrm{Mn}(\mathrm{OAc})_{2} .4 \mathrm{H}_{2} \mathrm{O} \quad(0.025 \mathrm{mmol}, 0.061 \mathrm{~g})$ in $10 \mathrm{ml}$, ethanolic solution of Schiff base (L) $(0.025 \mathrm{mmol}, 0.107 \mathrm{gm})$ in $10 \mathrm{ml}$ was added. The two solutions were mixed in $50 \mathrm{ml}$ round bottomed flask and the mixture was refluxed for 12-15 $\mathrm{h}$. The reaction mixture was concentrated to a small volume by evaporation method, on cooling metal complex crystallizes out. The crystallized metal complex was then filtered and washed it thoroughly with ethanol and dried under vacuum over anhydrous $\mathrm{CaCl}_{2}$.

(b) Synthesis of $\left[\mathrm{FeL}\left(\mathrm{H}_{2} \mathrm{O}\right)_{2}\right] 2 \mathrm{Cl}$

To an ethanolic solution of $\mathrm{FeCl}_{2} \cdot 2 \mathrm{H}_{2} \mathrm{O}(0.025 \mathrm{mmol}, 0.0418 \mathrm{~g})$ in $10 \mathrm{ml}$, an ethanolic solution of Schiff base (L) $(0.025 \mathrm{mmol}, 0.107 \mathrm{~g})$ was added and then the mixture was refluxed for $15 \mathrm{~h}$. The reaction mixture was evaporated to a small volume, on cooling solid metal complex was obtained. The metal complex was then washed with ethanol and dried under vacuum over anhydrous $\mathrm{CaCl}_{2}$.

(c) Synthesis of $\left[\mathrm{CoL}\left(\mathrm{H}_{2} \mathrm{O}\right)_{2}\right] 2 \mathrm{AcO}$

The ethanolic solution of $\mathrm{Co}(\mathrm{OAc})_{2} \cdot 4 \mathrm{H}_{2} \mathrm{O}(0.025 \mathrm{mmol}, 0.062 \mathrm{~g})$ in $10 \mathrm{ml}$ was added to ethanolic solution of Schiff base (L) $(0.025 \mathrm{mmol}, 0.107 \mathrm{~g})$ in $10 \mathrm{ml}$ and the mixture was refluxed for $10 \mathrm{~h}$. The reaction mixture was evaporated to a small volume, on cooling solid metal complex was obtained. The metal complex was then washed with ethanol and dried under vacuum over anhydrous $\mathrm{CaCl}_{2}$.

(d) Synthesis of complex[NiL]2Cl

The ethanolic solution of $\mathrm{NiCl}_{2} \cdot 6 \mathrm{H}_{2} \mathrm{O}(0.025 \mathrm{mmol}, 0.059 \mathrm{~g})$ in $10 \mathrm{ml}$ was added to ethanolic solution of Schiff base (L) $(0.025 \mathrm{mmol}, 0.107 \mathrm{~g})$ in $10 \mathrm{ml}$. The reaction mixture was refluxed in $50 \mathrm{ml}$ round bottom flask for $12 \mathrm{~h}$. The reaction mixture was evaporated to a small volume, on cooling solid metal complex thus obtained was washed with ethanol and dried under vacuum over anhydrous $\mathrm{CaCl}_{2}$. 
RASĀYAN J. Chem.

Vol. 13 | No. 1 |215 - 221| January - March | 2020

(e) Synthesis of complex[ZnL]2AcO

To ethanolic solution of $\mathrm{Zn}(\mathrm{OAc})_{2} \cdot 2 \mathrm{H}_{2} \mathrm{O}(0.025 \mathrm{mmol}, 0.046 \mathrm{~g})$ in $10 \mathrm{ml}$, ethanolic solution of Schiff base ( L) $(0.025 \mathrm{mmol}, 0.107 \mathrm{~g})$ was added. The reaction mixture was refluxed in $50 \mathrm{ml}$ round bottom flask for $16 \mathrm{~h}$. The reaction mixture was evaporated to a small volume, on cooling solid metal complex obtained was washed with ethanol and dried under vacuum over anhydrous $\mathrm{CaCl}_{2}$.

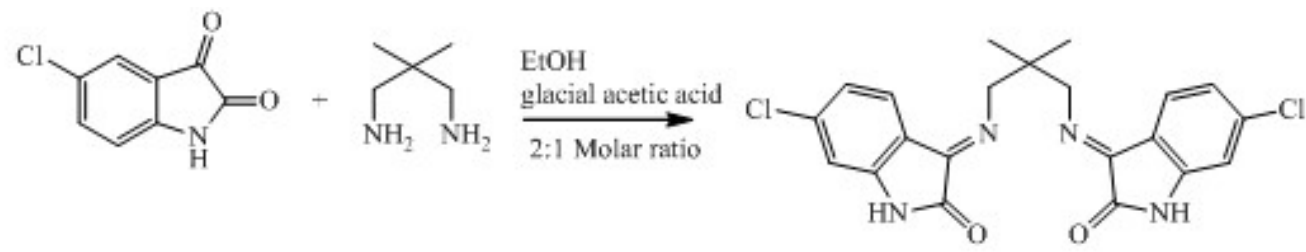

Scheme-1: Route of Synthesis of Ligand<smiles>CC(C)(C)CN=C1C(=O)NC2CC(Cl)C=CC12N=c1[nH]c(=O)c1=O</smiles>
$\underset{\text { Reflux at } 80-9090 \mathrm{C}}{\mathrm{Mn}(\mathrm{OAc})_{2}, 2 \mathrm{H}_{2} \mathrm{O}}$

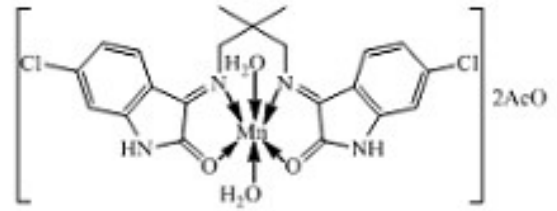<smiles>CC(C)(C)CN=C1C(=O)Nc2cc(Cl)ccc21</smiles>
$\underset{\text { Reflux at } 80-90^{\circ} \mathrm{C}}{\mathrm{FeCl}, 2 \mathrm{H}_{2} \mathrm{O}}$

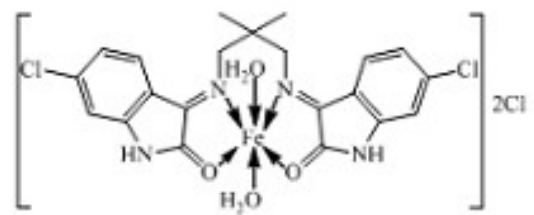<smiles>CC(C)(C)CN=C1C(=O)Nc2cc(Cl)ccc21</smiles>
$\underset{\text { Reflux at } 80-90^{\circ} \mathrm{CC}}{\mathrm{Co}(\mathrm{OAc})_{2} 2 \mathrm{H}_{2} \mathrm{O}}$

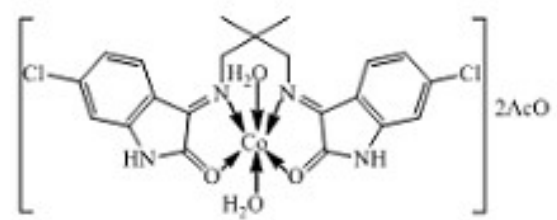<smiles>CC(C)(C)CN=C1C(=O)Nc2cc(Cl)ccc21</smiles>

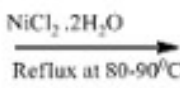<smiles>CC1(C)CN2C(=O)Nc3cc(Cl)ccc3C2=N1</smiles><smiles>CC(C)(C)CN=C1C(=O)Nc2cc(Cl)ccc21</smiles>
$\underset{\text { Reflux at } 80 \cdot 90^{1} \mathrm{C}}{\mathrm{Zn}(\mathrm{OAc})_{2}, 2 \mathrm{H}_{2} \mathrm{O}}$

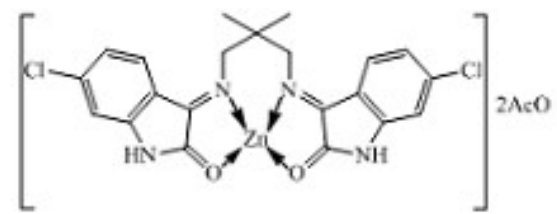

Scheme-2: Route for Synthesis of Metal Complexes

\section{RESULTS AND DISCUSSION}

We have developed a simple and highly reliable route for synthesis for Novel Schiff base Ligand and its complexes. This strategy can be successfully applied to prepare wide range of complexes of 5-Cholro isatine which can be widely used as potent compounds possess a wide spectrum of medicinal properties and have been studied for antibacterial activity and anti fungal activities. The newly synthesized ligand and its metal complexes are stable at room temperature in solid state. The ligand is soluble in common 
RASĀYAN J. Chem.

Vol. 13 | No. 1 |215 - 221| January - March | 2020

organic solvents but metal complexes are soluble in DMF and DMSO. The analytical data are in good agreement with the proposed stoichiometry of the complexes.

\section{Spectral Characterization of Ligand and Metal Complexes}

The IR spectra of ligand shows a sharp band at $1722.4 \mathrm{~cm}^{-1}$ and $1617 \mathrm{~cm}^{-1}$ which show the presence of $v(\mathrm{C}=\mathrm{O})$ and $v(\mathrm{C}=\mathrm{N})$ vibrations respectively. In the IR spectra of metal complexes, $v(\mathrm{C}=\mathrm{O})$ and $v(\mathrm{C}=\mathrm{N})$ are shifted by $10-20 \mathrm{~cm}^{-1}$ which shows the coordination of $(\mathrm{C}=\mathrm{O})$ and $(\mathrm{C}=\mathrm{N})$. A new band appeared in the range $460-485 \mathrm{~cm}^{-1}$ and $550-590 \mathrm{~cm}^{-1}$ may be assigned $v(\mathrm{M}-\mathrm{N})$ and $v(\mathrm{M}-\mathrm{O})$ vibrations respectively .

In the spectrums of UV-Vis spectroscopy, the electronic spectra of $\mathrm{Mn}$ (II) complexes show two bands in the regions 22500 - 22650 and $18500-18850 \mathrm{~cm}^{-1}$ which may be assigned to ${ }^{6} \mathrm{~A}_{1 \mathrm{~g}} \rightarrow{ }^{4} \mathrm{~T}_{2 \mathrm{~g}}$ and ${ }^{6} \mathrm{~A}_{1 \mathrm{~g}} \rightarrow{ }^{4} \mathrm{~T}_{1} \mathrm{~g}(\mathrm{G})$ transitions respectively, suggesting octahedral environment around the $\mathrm{Mn}(\mathrm{II}) \mathrm{ion}^{29}{ }^{2}$. The magnetic moment 4.88 $\mathrm{BM}$ is an additional evidence for an octahedral structure. The electronic spectra of the cobalt (II) complex showed three bands at 8780-8810, 17475-17775 and 30235-30270 $\mathrm{cm}^{-1}$, which may be assigned to ${ }^{4} \mathrm{~T}_{1 \mathrm{~g}} \rightarrow{ }^{4} \mathrm{~T}_{2 \mathrm{~g}}(\mathrm{~F}),{ }^{4} \mathrm{~T}_{1 \mathrm{~g}} \rightarrow{ }^{4} \mathrm{~T}_{1 \mathrm{~g}}(\mathrm{P})$, and ${ }^{4} \mathrm{~T}_{1 \mathrm{~g}} \rightarrow{ }^{3} \mathrm{~A}_{2 \mathrm{~g}}(\mathrm{~F})$ transitions, respectively, and suggested octahedral geometry around the cobalt ion. The electronic spectra of the Fe(II) complex display a broad band at $35600 \mathrm{~cm}^{-1}$ due to ${ }^{4} \mathrm{~T}_{1 \mathrm{~g}}(\mathrm{~F}) \rightarrow{ }^{4} \mathrm{~A}_{2 \mathrm{~g}}(\mathrm{~F})$ and two bands at 24510 and $10200 \mathrm{~cm}^{-1}$ assigned to ${ }^{4} \mathrm{~T}_{1 \mathrm{~g}}(\mathrm{~F}) \rightarrow$ ${ }^{4} \mathrm{~T}_{2 \mathrm{~g}}(\mathrm{P})$ and ${ }^{4} \mathrm{~T}_{1 \mathrm{~g}}(\mathrm{~F}) \rightarrow{ }^{4} \mathrm{~T}_{2 \mathrm{~g}}(\mathrm{~F})$ respectively, of an octahedral environment. The nickel(II) complex was insoluble in common organic solvents and water. The compound was soluble in coordinating solvents, pyridine and DMSO, presumably by displacing water molecules from the coordination sphere. The nickel(II) complex exhibited bands between $18400-21500 \mathrm{~cm}^{-1}$ assignable to the transitions ${ }^{1} \mathrm{~A}_{1 \mathrm{~g}} \rightarrow{ }^{1} \mathrm{~A}_{2 \mathrm{~g}}$ which are characteristic of nickel(II) Square planar geometry. Since zinc(II) ion has $\mathrm{d}^{10}$ configuration the absorption at $26910 \mathrm{~cm}^{-1}$ could be assigned to a charge transfer transition.

\section{${ }^{1} \mathrm{H}$ and ${ }^{13} \mathrm{C}$ NMR Spectra}

${ }^{1} \mathrm{H}$ NMR and ${ }^{13} \mathrm{C}$ NMR of ligand in DMSO- $\mathrm{d}_{6}$ solution show that they are NMR active. The ${ }^{1} \mathrm{H}-\mathrm{NMR}$ spectrum of free ligand show a singlet at $0.98 \mathrm{ppm}$ due to $\mathrm{CH}_{3}$ proton, $3.45 \mathrm{ppm}$ due to $\mathrm{CH}_{2}$ proton, and 7.30 due to Ar-CH respectively. ${ }^{13} \mathrm{C}-\mathrm{NMR}$ spectrum of free ligand show at $161.4 \mathrm{ppm}$ in the range due to imine carbon, $118.23 \mathrm{ppm}$ due Aromatic carbons, $153.88 \mathrm{ppm}$ due to $\mathrm{C}=\mathrm{O}$. Thus, ${ }^{1} \mathrm{H}$ and ${ }^{13} \mathrm{CNMR}$ spectral data support proposed structure of ligand and metal complexes and as well coordination behavior of ligand. The molar conductance $\left(\Lambda_{\mathrm{M}}\right)$ values of all metal complexes were measured in DMSO and show electrolyte nature of complexs. ${ }^{30}$

\section{L(3Z,3'Z)-3,3'-((2,2-dimethylpropane-1,3-diyl)bis(azanylyidene))bis(5-chloroindolin-2-one)}

Color: Light purple, Yield: $66 \%$, mp.: $264{ }^{0} \mathrm{C}$ decomposition, Analysis for $\mathrm{C}_{21} \mathrm{H}_{18} \mathrm{Cl}_{2} \mathrm{~N}_{4} \mathrm{O}_{2} ; \mathrm{C}, 58.75 ; \mathrm{H}$, 4.23; Cl, 16.52; N, 13.05; O, 7.45 found C, 58.80; H, 4.19; Cl, 16.55; N, 13.07; O, 7.39; IR (KBr) $v \mathrm{~cm}^{-1}$ : $3248(\mathrm{~N}-\mathrm{H}$ str. $), 1722.4$ (C=O str.), 1617 (C=N str.); ${ }^{1} \mathrm{H}$ NMR (DMSO-d 6 , $\delta$ ppm): $0.98\left(\mathrm{~d}, 2 \mathrm{H},-\mathrm{CH}_{3}\right), 3.45$ $\left(\mathrm{d}, 2 \mathrm{H},-\mathrm{CH}_{2}\right), 7.26-7.89(\mathrm{~m}, 6 \mathrm{H}, \mathrm{Ar}-\mathrm{CH}), 7.98(\mathrm{~d}, 2 \mathrm{H}, \mathrm{NH})$; Mass spectra (m/z): 429.29.

\section{Complex $\left[\mathrm{MnL}\left(\mathrm{H}_{2} \mathrm{O}\right)_{2}\right] .2 \mathrm{AcO}$}

Color:Brown,Yield:65.5\% Analysis for $\mathrm{C}_{21} \mathrm{H}_{22} \mathrm{Ac}_{2} \mathrm{Cl}_{2} \mathrm{MnN}_{4} \mathrm{O}_{6}, \quad \mathrm{C}, 25.03 ; \quad \mathrm{H}, \quad 2.20 ;$ Ac,45.12; $\mathrm{Cl}, 7.05 ; \mathrm{Mn}, 5.46 ; \mathrm{N}, 5.57$; O, 9.52 found $\mathrm{C}, 25.01 ; \mathrm{H}, 2.18 ; \mathrm{Ac}, 45.16 ; \mathrm{Cl}, 7.06 ; \mathrm{Mn}, 5.54 ; \mathrm{N}, 5.60 ; \mathrm{O}, 9.45$; IR (KBr) vcm ${ }^{-1}: 1710$ (C=O str.), 1609 (C=N str.), 490 (M-N str.), 601 (M-O str.); Mass spectra(m/z): 553.03.

\section{Complex $\left[\mathrm{FeL}\left(\mathrm{H}_{2} \mathrm{O}\right)_{2}\right] .2 \mathrm{Cl}$}

Color: Brown, Yield: 75.5\%, Analysis for $\mathrm{C}_{21} \mathrm{H}_{22} \mathrm{Cl}_{4} \mathrm{FeN}_{4} \mathrm{O}_{4} ; \mathrm{C}, 42.60 ; \mathrm{H}, 3.75 ; \mathrm{Cl}, 23.95 ; \mathrm{Fe}, 9.43 ; \mathrm{N}$, 9.46; O, 10.81 found $\mathrm{C}, 42.55 ; \mathrm{H}, 3.78 ; \mathrm{Cl}, 23.98 ; \mathrm{Fe}, 9.42 ; \mathrm{N}, 9.42 ; \mathrm{O}, 10.85 ; \mathrm{IR}(\mathrm{KBr}) \mathrm{vcm}^{-1}: 3241(\mathrm{~N}-\mathrm{H}$ str.),1712 (C=O str.),1612 (C=N str.) 480(M-N str.), 593 (M-O str.); Mass spectra(m/z): 589.97.

\section{Complex $\left[\mathrm{CoL}\left(\mathrm{H}_{2} \mathrm{O}\right)_{2}\right] .2 \mathrm{AcO}$}

Color: Brown, Yield: $63.9 \%$, Analysis for $\mathrm{C}_{21} \mathrm{H}_{22} \mathrm{Ac}_{2} \mathrm{CoN}_{4} \mathrm{O}_{6} ; \mathrm{C}, 24.97 ; \mathrm{H}, 2.19 ; \mathrm{Cl}, 7.02 ; \mathrm{N}, 5.55 ; \mathrm{O}$, 9.50;Ac, 44.94; Co, 5.83; found C, 24.90; H, 2.22; Cl, 7.01; N, 5.60; O, 9.50; Ac, 44.89; Co, 5.88 IR 
RASĀYAN J. Chem.

Vol. 13 | No. 1 | 215 - 221| January - March | 2020

(KBr) $v \mathrm{~cm}^{-1}: 3245$ (N-H str.), 1708 (C=O str.),1610 (C=N str.), 553(M-N str.), 654(M-O str.); Mass $\operatorname{spectra}(\mathrm{m} / \mathrm{z}): 557.02$.

\section{Complex[NiL]2Cl}

Color: Brown, Yield: $39.6 \%$, Analysis for $\mathrm{C}_{21} \mathrm{H}_{18} \mathrm{Cl}_{2} \mathrm{~N}_{4} \mathrm{NiO}_{2} ; \mathrm{C}, 51.69 ; \mathrm{H}, 3.72 ; \mathrm{Cl}, 14.53 ; \mathrm{N}, 11.48$; Ni, $12.03 ; \mathrm{O}, 6.56$ found $\mathrm{C}, 51.70 ; \mathrm{H}, 3.74 ; \mathrm{Cl}, 14.50 ; \mathrm{N}, 11.51 ; \mathrm{Ni}, 12.07 \mathrm{O}, 7.46 ; \mathrm{IR}(\mathrm{KBr}) \mathrm{vcm}^{-1}: 3242(\mathrm{~N}-\mathrm{H}$ str.), 1714 (C=O str.),1612 (C=N str.),450 (M-N str.), 580 (M-O str.); Mass spectra(m/z): 490.01.

\section{Complex[ZnL].2AcO}

Color: Brown, Yield: 38.4\%, Analysis for $\mathrm{C}_{21} \mathrm{H}_{18} \quad \mathrm{Ac}_{2} \mathrm{Cl}_{2} \quad \mathrm{ZnN}_{4} \mathrm{O}_{4} ; \mathrm{C}, 25.72 ; \mathrm{H}, 1.85 ; \mathrm{C}, 46.29$; $\mathrm{Cl}, 7.23 ; \mathrm{Zn}, 6.67 ; \mathrm{N}, 5.71 ; \mathrm{O}, 6.53$ found $\mathrm{C}, 25.75 ; \mathrm{H}, 1.88 ; \mathrm{C}, 46.25 ; \mathrm{Cl}, 7.25 ; \mathrm{Zn}, 6.70 ; \mathrm{N}, 5.73 ; \mathrm{O}, 6.54$ IR ( $\mathrm{KBr}) \mathrm{ccm}^{-1}: 3240$ (N-H str.),1712 (C=O str.),1610 (C=N str.), 483 (M-N str.),540 (M-O str.) ; Mass $\operatorname{spectra}(\mathrm{m} / \mathrm{z}): 527.99$.

\section{Antimicrobial Activities}

The antimicrobial activities of ligands and its complexes were tested in vitro against $S$. epidermidis, $E$. Coli, A. flavus, A. niger and C. lunata by reported method. ${ }^{31}$ On comparing the antimicrobial activities of Schiff base(L) and its metal (Mn, Fe, Co, Ni and $\mathrm{Zn}$ ) complexes, we found that the complexes exhibit more activity then that of the ligand. The increase in the activity of the complexes compared to that of the ligand could be explained on the basis of Overtone's concept and Tweedy's chelation theory ${ }^{32}$ Table-1. It has also been found that the ligand showed no activity against E.coli.

Table-1: Antimicrobial Effects of the Ligands and their Metal Complexes

\begin{tabular}{c|c|c|c|c|c|c}
\hline \multirow{2}{*}{ S.No. } & \multirow{2}{*}{ Compound } & \multicolumn{5}{|c}{ Inhibition Zone (mm) } \\
\cline { 3 - 7 } & & E.Coli & S.epidermidis & A.flavus & A.niger & C.lunata \\
\hline 1 & Schiff base(L) & --- & 6 & 9 & 11 & 10 \\
\hline 2 & {$\left[\mathrm{MnL}\left(\mathrm{H}_{2} \mathrm{O}\right)_{2}\right] .2 \mathrm{AcO}$} & 11 & 16 & 15 & 14 & 18 \\
\hline 3 & {$\left[\mathrm{FeL}\left(\mathrm{H}_{2} \mathrm{O}\right)_{2}\right] .2 \mathrm{Cl}$} & 15 & 15 & 14 & 16 & 15 \\
\hline 5 & {$\left[\mathrm{CoL}\left(\mathrm{H}_{2} \mathrm{O}\right)_{2}\right] .2 \mathrm{AcO}$} & 16 & 14 & 17 & 16 & 17 \\
\hline 6 & {$[\mathrm{NiL}] .2 \mathrm{Cl}$} & 14 & 16 & 18 & 14 & 19 \\
\hline 8 & {$[\mathrm{ZnL}] .2 \mathrm{AcO}$} & 12 & 12 & 15 & 15 & 16 \\
\hline
\end{tabular}

\section{CONCLUSION}

On the basis of above mentioned studies we have proposed the octahedral geometry for the all metal complexes except $\mathrm{Ni}$ (II) and $\mathrm{Zn}$ (II) complexes they show square planar geometry and the antimicrobial results showed that these metal complexes were more potent than that of ligand. The newly synthesized Schiff base (L) and its metal complexes were screened for their microbial activity against different pathogenic microbes for their antibacterial and antifungal activities using well defined methods. The compounds were screened for their antibacterial activity against E. coli, S. aureus, P. vulgaris and for antifungal activity against C. albicans and A. niger in potato dextrose agar medium.

\section{ACKNOWLEDGEMENT}

Authors are thankful to SAIF, Department of Chemistry, University of Delhi, Delhi for providing spectral facilities. Authors are also thankful to Head, Department of Chemistry ,DDU Gorakhpur University, Gorakhpur and Head, Chemistry Dept., MCM and Principal, Meerut College, Meerut for encouragement and providing necessary facilities.

\section{REFERENCES}

1. M. Wang, H. Zhu, K. Jin, D. Dai and L. Sun, Journal of Catalysis. 220, 2 (2003), DOI: 10.1016/s0021-9517(03)00306-3.

2. F. Marchetti, C. Pettinari, R. Pettinari, A. Cingolani, D. leonesiand and A. Lorenzotti Polyhedron. 18, 23(1999), DOI:1001016/s0277-5387(99)00230-2. 
RASĀYAN J. Chem.

Vol. 13 | No. 1 | 215 - 221| January - March | 2020

3. D. Mandal and B. Mandal, Rasayan Journal of Chemistry 12(2), 754(2019), DOI: $10.31788 /$ RJC.2019.1225230

4. V.Glover, J.M. Halket, P.J .Watkins, A.Clove, B.L. Goddwin and M.J. Sandler, Neurochemistry. 51,656(1988), DOI:10.1111/j.1471-4159.1988.tb01089.x.

5. S.K. Bhattacharya, V.Glover, I.McIntyre, G.Oxenkrug and M. Sandler, Neuroscience Letter ,92(2), 218(1988), DOI:10.1016/0304-3940(88)90064-X

6. S.K. Bhattacharya, S.K. Mitra, S.B Acharya, Journal of Psychopharmacol 5,202(1991), DOI: $10.1177 / 026988119100500304$.

7. M.S. Gil-Turner, M.E. Hay and W. Fenical, Science. 246, 116(1989), DOI:10.1126/Science.2781297.

8. M. Sahihovic, M. Pazalja, I.M. Dizdarevic, A. J. Mujkic, J. Suljagic, S.S. Halilovic and A. Sapcanin, Rasayan Journal of Chemistry, 11(3), 1074(2018), DOI:10.31788/RJC.2018.1133077

9. G. Puthilibai and S. Vasudhevan, Rasayan Journal of Chemistry, 12(2), 855(2019) DOI: $10.31788 /$ RJC.2019.1225230

10. A. Jarrahpour, D. khalili, E.D. Clercq, C.Salmi and J.M. Brunel, Molecules. 12, 1720(2007), DOI: $10.3390 / 12081720$.

11. J.F.M. Silva, S. J. Garden, and A. C. Pinto, Journal of Brazilian Chemical Society.12, 273(2001), DOI: $10.1590 / \mathrm{s} 0103-50532001000300002$.

12. A. P. Mishra, R. Mishra, R. Jain and S. Gupta, Mycobiology.40, 20(2012), DOI:10.5941/MYCO.2012.40.1.020.

13. Z. H. Chohan and M. F. Jaffery, Metal Based Drugs. 7, 265(2000), DOI:10.1155/MBD.2000.265.

14. J. R. Anacona and G. D. Silva, Journal of Chilean Chemical Society. 50, 447(2005), DOI: $10.4067 / \mathrm{s} 0717.97072005000200001$.

15. S. N. Pandeya, D. Sriram, G. Nath and E. De Clercq, Pharmaceutica Acta Helvetiae.74,11(1999), DOI: 10.1016/S0031.6865(99)00010-2.

16. R. S. Varma and W. L. Nobles, Journal of Medicinal Chemistry. 10,972(1967), DOI:10.1021/jm00315a060.

17. S. N. Pandeya, P. Yogeswari, D. Sriram, G. Nath, E. De Clercq, C. Pannecouque and M. Witvrouw, Chemotherapy. 45,192(1999), DOI:10.1159/000007182.

18. S.N. Pandeya, D.Sriram, G. Nath and E.De Clercq, European Journal of Medicinal Chemistry. 35,249(2000), DOI: 10.1016/S0223-5234(00)00125-2.

19. S. I. AL-Resayes, M. Shakir, A. Abbasi, K. M. Y. Amin and A. Lateef, Spectrochimica acta part A: Molecular and biomolecular spectroscopy, 93, 86(2012), DOI:10.1067/j.saa.2012.02.099.

20. S.A. Iman and R.S. Varma, Experientia.31,1287(1975), DOI:10.1007/BF01945784

21. M. E. Sarciron, P. Audin, I. Delebre, C. Gabrion and A. F. Petavy, Paris Journal of Pharmaceutical Sciences 82,605(1993), DOI: 10.1002/jps.2600820612.

22. Y. Soberanes, K. A. Lopez-Gastelum, J. Moreno-Urbalejo,A. J. Salazar-Medina, M. C. EstradaMontoya, R. Sugich-Miranda, J. Hernandez-Paredes, A. F. Gonzalez-Cordova, B.Vallejo-Cordoba, R. R. Sotelo-Mundo, E. F. Velazquez-Contreras and F. Rocha-Alonzo, Inorganic Chemistry Communications. 94,139 (2018), DOI:10.1016/j.inoche.2018.06.010.

23. V. A. Neacsu, C. Maxim, A. M. Madalan, M. Hillebrand, C. Gonzalez-Arellano, S. Soriano, E. Rentschler and M. Andruh, Polyhedron,150,77(2018), DOI:10.1016/j.poly.2018.05.007.

24. J. Mayans, M. Font-Bardia and A. Escuer, Dalton Transactions, 47, 8392(2018), DOI: $10.1039 / \mathrm{C} 8 \mathrm{DT} 01684 \mathrm{D}$.

25. (a) M. T. Kaczmarek, M. Zabiszak, M. Nowak and R. Jastrzab, Coordination Chemistry Reviews, 370, 42(2018), DOI:10.1016/j.ccy.2018.05.012. (b) N. A. Illan-Cabeza, S. B. Jimenez-Pulido, F. Hueso-Urena, M. J. Ramirez-Exposito, P. Sanchez-Sanchez, J. M. Martinez- Martos and M. N. Moreno-Carretero, Journal of Inorganic Biochemistry, 185, 52(2018), DOI:10.1016/j.jinorgbio.2018.04.022. (c) J. Valentova, S. Varenyi, P. Herich, P. Baran, A. Bilkova, J. Kozisek and L. Habala, Inorganica Chimica. Acta , 480, 16(2018), DOI:10.1016/j.ica.2018.04.058.

26. K. Al-Azawi, D. A. Duhaidahawi, A. Al-Ameiry, and A. A. H. Kadhum, Free Radicals and Antioxidants,9(1), 1(2019), DOI:10.5530/fra.2019.1.1. 
RASĀYAN J. Chem.

Vol. 13 | No. 1 | 215 - 221| January - March | 2020

27. R. M. Ramadan, A. K. Abu Al-Nasr and O. A. M. Ali, Journal of Molecular Structure, 1161, 100(2018), DOI:10.1016/j.molstruc.2018.01.071

28. H. Keypour, M. Mahmoudabadi, A. Shooshtari, L. Hosseinzadeh, F. Mohsenzadeh and R. W. Gable, Polyhedron , 127, 345(2017), DOI:10.1016/j.poly.2017.02.008.

29. A. Ahlawat, P. Khatkar, V. Singh and S. Asija, Research on Chemical Intermediates, 44, 4415(2018), DOI:10.1007/s11164-018-3395-z.

30. W. J. Geary, Coordination Chemistry Reviews, 7, 81 (1971), DOI:10.1016/S0010-8545(00)80009-0

31. J. Parekh, P. Inamdhar, R. Nair, S. Baluja and S. Chandra, Journal of Serbian Chemical Society 70, 1155, (2005), DOI:10.2298/JSC0510155P.

32. J.S. Sultan, S.M Lateaf and D.K. Rashid, Open Journal of Inorganic Chemistry, 5, 102, (2015), DOI: 10.4236/ojic.2015.54011.

[RJC-5571/2019] 